ISSN 2078-6441. Вісник Львівського університету. Серія географічна. 2013. Випуск 42. С. 170-178. Visnyk of the Lviv University. Series Geography. 2013. Issue 42. P. 170-178.

$338.48-6: 2-522$

\author{
ндрій ов льчук, ндрій нько \\ ьвівський н ціон льний університет імені в н \\ вул. . орошенк , 41, 79000, м. ьвів, кр їн, \\ e-mail:kaftour@ukr.net
}

ро н лізов но особливості функціонув ння трьох груп орг ніз торів релігійноп ломницького туризму. исвітлено особливості роботи туристичних фірм і релігійних структур із орг ніз ції п ломництв т релігійного туризму.

лючові слов : орг ніз ція релігійного туризму, орг ніз ція п ломництв, релігійнотуристичний об'єкт.

к 3 зн чено у н ших попередніх пр цях [1, с. 87; 2, с. 12 т ін.], терміни “релігійний туризм” і “п ломництво” не є синонім ми: вони не $з$ мінюють, доповнюють один одного. ричому відмінності між цими двом термін ми н теоретичному (дефініційному) рівні, розглянуті у н зв них пр цях, повністю узгоджуються із пр ктикою орг ніз ції як вл сне релігійно-туристичних, т к і п ломницьких подорожей. ижче про н лізуємо орг ніз торів релігійно-п ломницького туризму і з'ясуємо їхні відмінності в сегмент х релігійних турів т п ломницьких подорожей.

пр ктиці вітчизняного релігійно-туристичного руху серед орг ніз торів релігійного туризму і п ломництв можн виділити три групи орг ніз цій:

1) церковні (релігійно-конфесійні) структури різних рівнів, що з йм ються п ломницькою діяльністю;

2) світські гром дські орг ніз ції, що, з звич й, пов'яз ні з релігійними орг ніз ціями;

3) світські комерційно-бізнесові орг ніз ції - підприємств , що іноді теж можуть бути пов'яз ні із церковними структур ми, одн к здебільшого діють с мостійно.

ожн із цих груп м є свої суттєві особливості як щодо функціонув ння, т к і щодо орг ніз ції релігійно-туристичних чи п ломницьких подорожей.

ільшість із великих християнських конфесій (рівня церкви чи деномін ції), що діють в кр їні, т кож конфесії інших релігій (зокрем, ісл мські, іудейські т орієнт лістські) м ють у структурі певні орг ни, що відповід ють 3 здійснення п ломницьких подорожей своїх вірних. лежно від потреб вірних, вл сних можливостей т м сшт бу орг ніз ції ці орг ни може предст вляти одн людин з обмеженими функціями т розг лужен орг ніз ція з інтенсивними зовнішніми зв'язк ми. прикл д, у великих пр восл вних і к толицьких церкв х ( , , , т ін.) відповідно до їхньої внутрішньої орг ніз ційної структури - чотирирівневого церковного дміністр тивно-територі льного устрою, орг ни, що відповід ють 3 п ломницьку діяльність, т кож чотирирівневі (т бл. 1).

рім церковних територі льних упр влінь, п ломницькою діяльністю $з$ йм ються й окремі релігійні орг ніз ції в меж х кожної конфесії, зокрем , мон стирі, хоч і не всі. ернечі інституції т кож м ють кільк рівневі дміністр тивні структури. пр ктиці

(C) ов льчук ., Нько ., 2013 
тр пляється, що п ломницьк діяльність окремих мон стирів т п р фій іноді зіст вн із діяльністю цілих п ломницьких служб при єп рхі льних упр вліннях. прикл д, у ьвові поряд із п ломницьким центром “ жерел духовності”, який діє при олодіжній комісії всієї ьвівської рхієп рхії , досить відомими є п ломницький центр “ тері ожої еуст нної омочі” (головний офіс при хр мі окрови ресвятої огородиці н вул. ич ківській із філі л ми в інших обл сних центр х) т п ломницький центр “ дія”, що діє при церкві ознесіння осподнього н вул. олодимир еликого. іншого боку, п ломницьк діяльність окремих цілих регіон льних (єп рхільних) упр влінь "не дотягує" до п ломницької діяльності окремих священиків i п р фій із сусідніх єп рхій. е з лежить від н явності попиту (тобто потреб і можливостей с мих вірних), н явності релігійно-туристичних ресурсів, енергійності орг ніз торів, допомоги мирянських орг ніз цій і окремих мирян-вірних т інших чинників, що вл сне й формують інтенсивність релігійно-п ломницької діяльності.

блиця 1

івні упр вління церковною п ломницькою діяльністю в $\quad$ кр їні

\begin{tabular}{|c|c|c|}
\hline \multirow{2}{*}{ івні упр вління } & $\begin{array}{c}\text { івні } \\
\text { ( дміністр тивно-терито- } \\
\text { рі льного устрою) церков }\end{array}$ & $\begin{array}{c}\text { ідповід льні з } \\
\text { п ломницьку діяльність }\end{array}$ \\
\hline \multirow{2}{*}{ сеукр їнський (всецерковний) } & $\begin{array}{c}\text { тері рх, } \\
\text { митрополит тощо }\end{array}$ & $\begin{array}{c}\text { ентр льні п ломницькі } \\
\text { центри т служби }\end{array}$ \\
\hline егіон льний (єп рхі льний) & $\begin{array}{c}\text { п рхія, єпископство, } \\
\text { дієцезія тощо }\end{array}$ & $\begin{array}{c}\text { п рхі льні п ломницькі } \\
\text { центри т служби }\end{array}$ \\
\hline йонний (пресвітері льний) & ек н т, бл гочиння тощо & ек н, бл гочинний тощо \\
\hline ісцевий (п р фі льний) & р фія тощо & стоятелі п р фій \\
\hline
\end{tabular}

ентр льні п ломницькі служби т центри здійснюють з г льне керівництво релігійно-п ломницьким туризмом у руслі церковної політики т догм тики. прикл д, утворений 2010 р. трі рший п ломницький центр ( $\quad$ ) при трі ршій курії м $є$ головним з вд нням розвиток п ломницької сфери 3 вдяки впорядкув нню релігійного комплексу, господ рської т п ломницької інфр структури, т кож 3 доволенню проч нських і туристичних потреб з собом орг нізов них, безпечних, 3 якісним інформ ційним і духовним супроводом п ломницьких подорожей. к діяльність м є: 1) місіонерську скл дову, зокрем поширюються зн ння про , іiі історію, вчення, с кр льну сп дщину; 2) економічну скл дову, зокрем з лученням отрим них від релігійно-п ломницького туризму фін нсів для потреб т розвитку еркви; 3) суспільно-духовну і культурно-пізн в льну скл дову.

К з зн чено в офіційних джерел $\mathrm{x}$, довгостроковими з вд ннями $є$ : створення умов для якн йширшої ре ліз ції потреб вітчизняних т іноземних п ломників і туристів, н л годження співпр ці з гром д ми укр їнців ді спори в сфері п ломництв , з поч ткув ння співпр ці між укр їнськими $т$ іноземними уч сник ми п ломницької г лузі, з безпечення вз ємодії з міжн родними орг ніз ціями в г лузі релігійного туризму і п ломництв , збільшення кількості вітчизняних т іноземних п ломників і туристів, стимулюв ння розвитку суч сної соці льної т інженерної інфр структури п ломницьких місць. чікув ними результ т ми діяльності ентру повинні ст ти: розвинутий с кр льний потенці л, обізн ність п ломників і туристів про $\quad$ т її с кр льну сп дщину, п ломницьк сфер , інтегров н 
у світовий ринок, зміцнен економік соб ми для досягнення мети є: інформ ційн діяльність і рекл м (полігр фічні продукти, сувенірні продукти, веб-с йт, нтернет-м г зин); торговельн діяльність (торговельн мереж, нтернет-м г зин, експозиційно-торговельний 3 л, вл сн торговельн орг ніз ція); п ломництво i релігійний туризм (прощі, п ломництв, тури, вл сн туристичн діяльність). ля поширення інформ ції про п ломницькі об'єкти т діяльність ентру вид но м пу “ вятині кр їни”, путівник “ ломницькі місця ", буклети тощо. рг ніз ція п ломництв святинями н території кр їни є пріоритетною для ; ним н йближчим ч сом будуть розроблені й п спортизов ні п ломницькі м ршрути [3].

вд ння регіон льної п ломницької служби є вужчими, одн к не менш конкретними. прикл д, п ломницький центр “ с нн”, що діє при олинській єп рхії , пропонує широкий вибір м ршрутів як в кр їні, т к і з іiї меж ми, н д $є$ сукупність туристичних послуг т всебічну інформ ційну підтримку. о функціон льних обов'язків цього п ломницького центру н леж ть: відновлення т проп гув ння п ломницьких тр дицій; орг ніз ція п ломництв до святинь; популяриз ція волинських і укр їнських святинь т озн йомлення із з рубіжними; співпр ця із держ вними т прив тними туристичними орг ніз ціями тощо [4].

к 6 чимо, релігійно-конфесійні структури при орг ніз ції п ломницької діяльності пр гнуть до співпр ці зі світськими підприємств ми т уст нов ми. редст вники другої групи орг ніз торів релігійного туризму і п ломництв - світські гром дські орг ніз ції - ч сто пов'яз ні з конкретними конфесіями, хоч особливо не фішують свою 3 нг жов ність. ут перев ж ють молодіжні орг ніз ції, бр тств т інші мирянські спільноти, н прикл д, (“ кр їнськ молодь - ристові”), олодіжне тов риство “ бнов”, пілк пр восл вної молоді кр їни, оюз пр восл вних бр тств, p тство св. постол ндрія ервозв нного, центри із роботи з сім'єю й молоддю т б г то інших. і спільноти можуть вз ємодіяти із релігійними орг ніз ціями, зокрем “пост ч ючи” ім п ломників. роте ч сто вони є втономними орг ніз тор ми п ломництв до святинь цієї чи іншої конфесії чи релігії із з лученням священнослужителів відповідної конфесії чи релігії. сто це неприбуткові гром дські орг ніз ції, які змушені шук ти п ртнерів серед підприємств туристичної індустрії, що м ють ліцензію н туристичну діяльність.

к 3 зн чено р ніше [1, с. 87; 2, с. 9, т бл. 1.1], п ломницькі подорожі м ють свої екскурсійні форми подорожей, що трив ють, головно, менше 24 год. е т кі форми п ломництв, як хресн ход і відпуст. ресн ход може бути в меж х одного поселення і трив є з звич й кільк годин, може бути в сусідню обл сть і трив ти цілий день. ідпуст - подорож у певні дні до певних святинь (хр мів - “хр мовий пр зник”, чудотворних ікон тощо), відвідув ння яких пов'яз не із прощенням гріхів с ме в цей день. ідпуст може трив ти від кількох годин до кількох днів (тоді потрібн ночівля, і це вже більше подібне н тур).

ерхня ч сов меж трив лості подорожі в п ломництві ще різном нітніш і "розмитіш ”, ніж у с мому туризмі (від кількох місяців до 6-12 місяців і кількох років).

прикл д, тимч сове прожив ння європейця у будистських чи індуїстських мон стирях ( шр м х) зії з метою духовних пр ктик може трив ти кільк років і це вже більше подібне н постійне місце прожив ння, ніж н п ломництво. ому доцільно було 6 у меж х усього п ломницького руху з його ч совими меж ми від кількох годин до кількох років виділяти вл сне п ломництво - подорожі трив лістю від кількох днів до кількох тижнів, оскільки т кі подорожі 3 технологією орг ніз ції і здійснення 
подібні до релігійно-туристичних поїздок. 3 н логією 3 релігійним туризмом доцільно 6 н зв ти т кі п ломницькі подорожі $n$ ломницькими тур ми. дн к термін “П ломницький тур” досить різко критикують деякі релігієзн вці і богослови, мовляв: “П ломники - це не туристи, релігійний тур лише ззовні н г дує п ломництво, оскільки тут нем духовної скл дової. ому ми утримув тимемося від вжив ння термін "П ломницькі тури", з мінюючи його н безумовно ширший з змістом термін “п ломницькі подорожі”.

релігійні, і пов’яз ні із ними гром дські орг ніз ції досить ктивно орг нізовують вл сне короткотрив лі відпусти і хресні ходи, т кож середньотрив лі п ломницькі подорожі. овготрив лі ж подорожі (як і кільк годинні поїздки “н пр зник”) здебільшого орг нізовують с мі п ломники.

ст ння груп орг ніз торів релігійно-п ломницького туризму - комерційні підприємств - н йбільше предст влен туристичними фірм ми. зн чимо, що туристичні фірми досить ч сто використовують релігійно-туристичні ресурси для формув ння подорожей різної тем тики, зокрем, в ході нерелігійних і неп ломницьких турів.

прикл д, крім релігійно-туристичних і п ломницьких подорожей, релігійнотуристичні об'єкти використовують у культових, пізн в льно-екскурсійних, риту льномеморі льних, ност льгійно-синтемент льних, лікув льно-оздоровчих, весільношлюбних т деяких інших вид х турів (т бл. 2). кож релігійні об'єкти є метою т ких нетуристичних подорожей, як місіонерство і “н уковий туризм”. ісіонерство (від л т. missio - відсил ння, посил ння, доручення) - це поширення предст вник ми певної конфесії свого віровчення серед конфесійно чужого н селення бо серед невірних. ісіонерство, що здійснюють з бороненими метод ми: силою, примусом, “зомбув нням” тощо досить ч сто н зив ють прозелітизмом. одорожі з метою місіонерств і/чи прозелітизму, хоч їх і проводять релігійні діячі з релігійними з вд ннями, не можуть бути ні п ломницькими, ні туристичними, оскільки тут нем є ні мети поклоніння, ні туристичної мети, є суто професійн діяльність священнослужителів.

віть віз , яку вид ють місіонер м при перетині кордону, не туристичн , релігійн .

к зв ного “н укового туризму” н спр вді не існує, оскільки подорожі з н уковою метою є не туризмом, видом професійної діяльності. ослідницьк діяльність н уковців - це вид робіт, з який $є$ опл т , це суперечить одному із фунд мент льних визн чень туризму - витр т грошей під ч с подорожі, не їх з робіток. одорожі н уковців (як туристів) до релігійно-туристичних об'єктів можуть бути пізн в льними бо н вч льними, одн к це вже, відповідно, культурно-пізн в льний чи н вч льний туризм. ому ні в релігійному туризмі і в п ломництві, ні в будь-якому іншому виді туризму з метою подорожі не може бути “н укових поїздок" у принципі, отже, твердження про “н уковий туризм” є помилковим.

кож поширеними є поїздки керівництв конфесій із різном нітними релігійними з вд ннями: візит ція єп рхій і п р фій, відвідув ння очільників інших конфесій, поклоніння окремим п ломницьким об'єкт м тощо. осить ч сто в інформ ційних джерел х (особливо у з соб х м сової інформ ції) т кі подорожі н зив ють “П ломництвом”. дн к це не тільки і не стільки п ломницькі поїздки, як знову ж т ки: професійн діяльність. кщо п п , п трі рх чи єпископ здійснює подорож до святині з метою поклоніння як прив тн особ, то це спр вді п ломництво, т якщо він предст вляє себе як керівник релігійної орг ніз ції, то це вже не п ломництво і не релігійний туризм, офіційн робоч поїздк , нех й н віть б г тоцільов . 
еп ломницькі і нерелігійно-туристичні подорожі, що передб ч ють використ ння релігійно-туристичних об'єктів ${ }^{1}$

\begin{tabular}{|c|c|c|}
\hline ур чи подорож & утність туру чи подорожі & $\begin{array}{c}\text { икористовув ні релігійно- } \\
\text { туристичні елементи }\end{array}$ \\
\hline \multicolumn{3}{|c|}{ уристичні подорожі-тури } \\
\hline ультові тури & $\begin{array}{c}\text { оклоніння п м’яті своїх кумирів: } \\
\text { політичних діячів, спів ків, поетів, } \\
\text { спортсменів тощо }\end{array}$ & $\begin{array}{c}\text { божнюв ння своїх кумирів; } \\
\text { могили, м взолеї, п м’ятники тощо }\end{array}$ \\
\hline иту льні тури & \multirow{2}{*}{$\begin{array}{l}\text { оїздки, зокрем для ветер нів, } \\
\text { н могили (зокрем , воїнів), } \\
\text { місця боїв т бойової сл ви, } \\
\text { уч сть у церемоніях, обряд х }\end{array}$} & \multirow{2}{*}{$\begin{array}{c}\text { елігійні обряди; } \\
\text { уч сть священнослужителів; } \\
\text { могили, меморі ли тощо }\end{array}$} \\
\hline еморі льні тури & & \\
\hline ост льгійні тури & $\begin{array}{c}\text { ідвідув ння місць свого } \\
\text { н родження і життя }\end{array}$ & \multirow{2}{*}{$\begin{array}{c}\text { ультові будівлі; релігійні обряди; } \\
\text { уч сть священнослужителів; } \\
\text { могили т ін. }\end{array}$} \\
\hline ентимент льні тури & ідвідув ння рідних т їхніх могил & \\
\hline ізн в льні тури & \multirow{3}{*}{$\begin{array}{c}\text { ідвідув ння об’єктів зі зн чною } \\
\text { культурно-пізн в льною цінністю }\end{array}$} & \multirow{3}{*}{$\begin{array}{c}\text { р ми, мон стирі, с кр льні } \\
\text { й т ф льні л ндш фти; } \\
\text { культові речі; релігійні обряди; } \\
\text { священнослужителі т ін. }\end{array}$} \\
\hline кскурсійні тури & & \\
\hline кскурсії & & \\
\hline любні тури & ошуки супутник життя & \multirow{2}{*}{$\begin{array}{c}\text { елігійні обряди; } \\
\text { уч сть священнослужителів; } \\
\text { культові будівлі тощо } \\
\end{array}$} \\
\hline есільні тури & $\begin{array}{l}\text { дійснення церемонії одруження } \\
\text { і проведення медового місяця }\end{array}$ & \\
\hline ікув льні тури & \multirow{2}{*}{$\begin{array}{c}\text { ідвідув ння курортів, оздоровчих } \\
\text { з кл дів для поліпшення фізичного } \\
\text { і духовного с мопочуття }\end{array}$} & \multirow{2}{*}{$\begin{array}{c}\text { уховні пр ктики, медит ції, } \\
\text { впр ви; релігійні обряди; уч сть } \\
\text { священнослужителів т ін. }\end{array}$} \\
\hline здоровчі тури & & \\
\hline тногр фічні тури & $\begin{array}{l}\text { ідвідув ння м лих н родів/етносів } \\
\text { для пізн ння їхнього життя і побуту }\end{array}$ & $\begin{array}{c}\text { ультові будівлі й речі; } \\
\text { релігійні обряди тощо }\end{array}$ \\
\hline кзотичні тури & $\begin{array}{c}\text { се, що незвич йне й екзотичне, } \\
\text { зокрем , пов'яз не із релігійною } \\
\text { сферою }\end{array}$ & $\begin{array}{c}\text { прикл д, прожив ння } \\
\text { у мон стирях (не для духовності, } \\
\text { з р ди цік вості) т ін. } \\
\end{array}$ \\
\hline \multicolumn{3}{|c|}{ етуристичні подорожі } \\
\hline $\begin{array}{c}\text { к зв ний } \\
\text { “н уковий туризм” }\end{array}$ & $\begin{array}{c}\text { омилково виділено б г тьм } \\
\text { втор ми в різних вид х туризму, } \\
\text { зокрем і в релігійно- } \\
\text { п ломницькому туризмі }\end{array}$ & $\begin{array}{c}\text { ивчення різном нітних об’єктів } \\
\text { релігійної сфери із професійною } \\
\text { метою (що є опл чув ною } \\
\text { діяльністю і суперечить основ м } \\
\text { туризму) }\end{array}$ \\
\hline $\begin{array}{c}\text { стирські } \\
\text { відвідув ння }\end{array}$ & $\begin{array}{l}\text { ідвідув ння вірних (п стви), } \\
\text { зокрем релігійними очільник ми } \\
\text { (п пою, п трі рх ми тощо) }\end{array}$ & \multirow{2}{*}{$\begin{array}{l}\text { рофесійн діяльність } \\
\text { священнослужителів }\end{array}$} \\
\hline $\begin{array}{r}\text { ісіонерство } \\
\text { і прозелітизм }\end{array}$ & $\begin{array}{c}\text { вернення нових вірних } \\
3 \text { допомогою проповідей, переко- } \\
\text { нув нь т } 6 \text { г тьох інших з собів }\end{array}$ & \\
\hline
\end{tabular}

1 г д ємо, що релігійно-туристичні об'єкти - це м тері льні ( т кож нем тері льні (с кр льні)) об'єкти (чи явищ , ефекти), які використовують, можуть використовув ти чи використовув ли р ніше в релігійній діяльності, перев жно є святинями для певної ч стини віруючих (для певної релігії, релігійного н пряму, течії, конфесії тощо) і доступні для їхнього п ломництв , т кож для відвідув ння турист ми т екскурс нт ми $[1$, с. $91 ; 2$, с. 15]. 
уристичних фірм, що спеці лізуються н суто релігійно-туристичних подорож х, неб г то. е менше є світських підприємств, що 3 йм ються орг ніз цією вл сне п ломницьких подорожей. рг ніз цію п ломницьких подорожей нерелігійними орг ніз ціями не віт ють, н віть критикують не лише церковні кол, й світські особи. в ж ють, що туристичн фірм, орг нізовуючи необхідний п кет послуг (прожив ння, х рчув ння, проїзд, віз , тр нсфер т ін.), не може орг нізув ти “духовної скл дової”, що є н йпершою спр вою для п ломництв . іншого боку, відсутність можливості отрим ти дозвіл (ліцензію) н туристичну діяльність змушує релігійні орг ніз ції йти н співпр цю із туристичними фірм ми. ому т к с мо, як терміни “релігійний туризм” і “п ломництво” доповнюють один одного, т к і пр ктичн орг ніз ція п ломницької подорожі, менше - релігійного туру, потребує співпр ці релігійної орг ніз ції і туристичної фірми. мовно можн ск з ти, що в р зі орг ніз ції релігійно-п ломницького туризму туристичн фірм відповід є більше 3 м тері льне,

церковн п ломницьк служб - $з$ духовне. озглянемо особливості т кої співпр ці між релігійними і підприємницькими структур ми (т бл. 3).

блиця 3

озподіл функцій між п ломницькою службою конфесії і туристичною фірмою в р зі орг ніз ції релігійно-п ломницького туризму

\begin{tabular}{|c|c|c|}
\hline $\begin{array}{l}\text { кл дові ет пи орг ніз ції } \\
\text { і проведення подорожі }\end{array}$ & $\begin{array}{l}\text { ломницьк } \\
\text { подорож }\end{array}$ & елігійний тур \\
\hline изн чення з г льної стр тегії подорожі & $*$ & $* *$ \\
\hline л нув ння м ршруту і послуг & $($ H.3.***) & \\
\hline омовленості із пост ч льник ми послуг & (H.3.) & \\
\hline $\begin{array}{l}\text { омовленості про відвідув ння релігійно- } \\
\text { туристичних об'єктів }\end{array}$ & & (н.3.) \\
\hline озр хунок в ртості і скл д ння прогр ми подорожі & (н.3.) & \\
\hline нформ ція і рекл м & (н.3.) & (н.3.) \\
\hline екоменд ція н подорож від священнослужителя & & (H.3.) \\
\hline рийом документів і грошей & (H.3.) & \\
\hline ироблення візи, стр хув ння т ін. (у р зі потреби) & (H.3.) & \\
\hline упровід священнослужителя & & (H.3.) \\
\hline упровід керівник групи & (H.3.) & \\
\hline н ліз проведеної подорожі і вз єморозр хунки & (H.3.) & \\
\hline
\end{tabular}

* - - релігійн орг ніз ція (тобто відповід льний з п ломництво у структурі конфесії)

** $\quad$ - пр цівники туристичної фірми

*** н.з. - може бути не 3 вжди

к 6 чимо $з$ т бл. 3, у р зі орг ніз ції п ломницької подорожі, може бути дв в рі нти: ) п ломницькі структури конфесії с мостійно, без допомоги світських

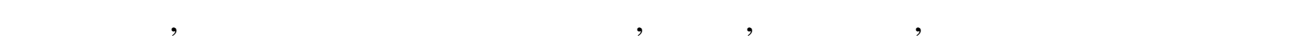
з безпечити подорож усім необхідним: від візи до тр нспорту і прожив ння; б) до орг ніз ції п ломництв ктивно долуч ються туристичні фірми, причому релігійні орг ніз ції з лиш ють 3 собою повний контроль 3 орг ніз цією подорожі і з скл дом iii уч сників. окрем, т кі ключові елементи п ломництв, як визн чення з г льної стр тегії подорожі (мет, цілі, ч сові т фін нсові межі тощо), вибір п ломницьких об'єктів, контроль 3 рівнем духовності, дотрим ння церковних пр вил і обрядів повністю з леж ть від релігійної орг ніз ції. 
онтроль $з$ рівнем духовності і дотрим ння церковних пр вил т релігійних обрядів досяг ється присутністю священнослужителів (одного чи кількох), що обов'язково повинні супроводжув ти п ломників. прикл д, греко-к толицькі священики допом г ють глибше пережити п ломництво через духовні бесіди і н уку, ожественну літургію т спільні молитви, що вони ч сто с мі проводять, святу т йну сповіді тощо. ля контролю з рівнем духовності кожного уч сник п ломницької подорожі, під ч с прийому документів вим г ють (особливо в р зі орг ніз ції з кордонної поїздки) рекоменд цію н подорож від священик, який служить н п р фії п ломник .

е є обов'язковим, оскільки в п ломницькі подорожі беруть лише осіб, які спр вді хочуть духовно зб г титися, не поїх ти в туристичну поїздку. тупінь мор льності п ломник якр з і визн ч є священик. е н стільки в жливо, що у ьвівській рхієп рхії н віть визн чили єдину форму рекоменд ції священик із фотогр фією м йбутнього п ломник .

рім рекоменд ції священик, у п ломницькому центрі “ жерел духовності” ьвівської рхієп рхії у р зі орг ніз ції з рубіжного п ломництв т кож вим г ють: 1) з яву п ломник визн ченої форми; 2) нкету н візу; 3) дв кольорові фото $3,5 \times 4,5$ см; чітке, чисте т контр стне, видрукув не н п пері високої якості н білому фоні, фото не ст рше шести місяців, що д є підст ви ідентифікув ти з явник , зроблене нф с (прямо), яке вир зно відобр ж є очі т обличчя з двох боків від верхньої ч стини голови до верхньої ч стини пліч (у т кий спосіб, щоб обличчя 3 йм ло 70-80\% фотогр фії), фото повинно предст вляти особу без головного убору, як дивиться прямо, із з мкнутими вуст ми, обличчя не може бути з крите волоссям.

вип дку осіб, які носять окуляри, до фотогр фії є т кі вимоги: нез темнені лінзи, опр в не може 3 крив ти жодної ч стини ок, не м є бути будь-яких світлових ефектів; 4) з кордонний п спорт т копія першої сторінки 3 кордонного п спорт .

спорт повинен містити підпис т бути дійсним щон йменше три місяці від д ти з кінчення дії візи, т кож містити щон йменше дві чисті сторінки (призн чені для візи). спорти прийм ють без дод ткових обкл динок, н прикл д: шкіряних, пл стикових. вип дку н явності інших з кордонних п спортів треб дод ти їх до візової нкети (оригін л і ксерокопія); 5) внутрішній п спорт (оригін л і ксерокопія сторінок 3 особовими д ними і реєстр цію про місце прожив ння); 6) довідк з місця пр ці із з зн ченням пос ди і розміру з робітної пл ти 3 ост нні шість місяців, т кож для підприємців - копія реєстр ції підприємств місцевими орг н ми вл ди, для студентів - довідк 3 н вч льного з кл ду. вип дку подорожі, як відбув ється протягом н вч льного року, т кож дозвіл про відсутність н з няттях; для пенсіонерів т інв лідів - пенсійне посвідчення т посвідчення інв лід (оригін л і ксерокопія); 7) якщо м йбутній п ломник $є$ неповнолітньою особою $\mathrm{T}$ подорожує $\mathrm{c}$ м бо в супроводі одного з б тьків, потрібне долучення оригін лу і ксерокопії письмової з яви - згоди іншого з б тьків бо опікун (оригін л і ксерокопія). вип дку, коли отрим ння згоди є неможливим, необхідно под ти документ, який пояснює причину відсутності згоди (н прикл д: довідк м тері-одиночки бо інший документ); т кож свідоцтво про н родження (оригін л і ксерокопія) т ксерокопія внутрішніх п спортів б тьків бо опікун, у вип дку спільної подорожі - копії дійсних віз [5].

кі вимоги до документ ції пов'яз ні, перш з все, із візовими форм льностями т прикордонним контролем, їх обов'язково ст влять і перед п ломник ми, і перед релігійними турист ми. кож для них перед подорожжю орг ніз тори розробляють 
певні пор ди, що допом г ють д птув тися до умов подорожі і до с мого місця перебув ння (дестин ції).

ході орг ніз ції релігійного туру туристичн фірм може діяти с мостійно, без допомоги предст вників релігійних орг ніз цій (див. т бл. 3). роте “релігійність” т кого туру можуть ст вити під сумнів перш 3 все с мі м йбутні туристи. ому деякі туристичні фірми т кож ст р ються отримув ти рекоменд цію священнослужителів, їхній супровід під ч с с мої подорожі, допомогу у домовленості з відвідув ння відповідних хр мів, мон стирів тощо. нколи т к домовленість може д ти відчутні знижки н розміщення чи х рчув ння при релігійно-туристичних об'єКт х, порівняно із готелями і рестор н ми. елігійні орг ніз ції, відчув ючи духовність і потрібність проведення певних релігійних турів фірм ми, можуть їх рекомендув ти своїм вірним, збільшуючи клієнтуру фірм. кож туристичні фірми можуть рекл мув ти п ломницькі подорожі “своїх" релігійних орг ніз цій, отримуючи від співпр ці з ними вз ємну вигоду.

1. ов льчук. ормув ння понятійно-термінологічного п р ту релігійного туризму і п ломництв / . ов льчук // існик ьвів. ун-ту. ер. міжн р. відносини. 2012. - ип. 29, ч. 2. - . 86-92.

2. ов льчук. елігійний туризм в кр їні : [н вч. посібник] / . ов льчук, . дніч нський, . утинський [т ін.]. - ьвів : ім. в н р нК, 2013. $420 \mathrm{c}$.

3. www.ugcc.org.ua.

4. www.osanna.in.ua - ломницький центр олинської єп рхії

5. www.pilgrimage.org.ua.

\author{
m ття: н дійшл до ред кцї̈ 17.07.2013 \\ доопр цьов н 22.08 .2013 \\ прийнят до друку 10.10.2013
}

\title{
ORGANIZERS OF PILGRIMAGE AND RELIGIOUS TOURISM
}

\author{
Andriy Kovalchuk, Andriy Man'ko \\ Ivan Franko National University of Lviv, \\ P. Doroshenko Str., 41, UA - 79000 Lviv, Ukraine, \\ e-mail: kaftour@ukr.net
}

Particularity of function of three groups of organizers of religious-pilgrimage tourism was analyzed Particularity of works of tourist firms and religious organizations by arrange pilgrimage and religious tourism was shown in research.

Key words: organize religious tourism, organize pilgrimage, religious tourism object. 


\author{
ндрей ов льчук, ндрей нько \\ ьвовский н цион льный университет имени в н \\ ул. . орошенко, 41, 79000, ьвов, кр ин, \\ e-mail:kaftour@ukr.net
}

ро н лизиров но особенности функциониров ния трех групп орг низ торов религиозноп ломнического туризм · ссмотрено особенности р боты туристических фирм и религиозных структур из орг низ ции п ломничеств и религиозного туризм.

лючевые слов : орг низ ция религиозного туризм, орг низ ция п ломничеств , религиозно-туристический объект. 